\title{
Reflections on the Performance Evaluation of Expenditure in Colleges and Universities
}

\author{
Biao Liu \\ Jiangxi Science \& Technology Normal University, finance department, \\ Jiangxi, Nanchang, 330013
}

\begin{abstract}
In recent years, colleges and universities in China got rapid development. In order to improve the efficiency of university expenditure management, so as to ensure the financial status of colleges and universities is in normal operation, it is very important to strengthen the evaluation performance of university expenditure. On the basis of a brief summary of the expenditure of colleges and universities, this article further explores the strategies to strengthen the performance evaluation of university expenditure, with a view to provide some valuable reference suggestions for the improvement of the management of the performance evaluation of funds expenditure.

Keywords: expenditure of colleges and universities, expenditure performance, evaluation thinking

\section{Introduction}

With the reform of the management system of higher education in China, the management requirements of the performance of university expenditure will gradually become strict. From the status quo, most of Chinese colleges and universities in the performance of expenditure management problems, such as: weak awareness of performance management, performance management procedures too much. In order to improve the overall management level of colleges and universities, this paper is of great significance to the research on the performance evaluation of university expenditure.
\end{abstract}




\section{The content of expenditure of colleges and universities}

\subsection{The concept of university expenditure}

Expenditure on higher education, also known as expenditure on higher education, refers to the cost of education applied by institutions of higher learning in China. Expenditure on education in colleges and universities includes: first, university education office expenses; second, university education basic investment class funds. Because of the special nature of the funding of higher education, is to ensure that Chinese institutions of higher learning in the normal operation of the necessary conditions. How to improve the management efficiency of university education funds, so as to ensure the normal operation of our university finance, requires the education sector and financial management departments and it should be issued a series of corresponding funding policies for higher education to solve this problem from the root. Higher education funding policy that from a macro point of view, the allocation of expenditure, in order to achieve the purpose of the use of management funds.

Chinese education expenditure on financial management, there are already clear management standards and rules and regulations. For example: "the CPC Central Committee and State Council on the classification of institutions and institutions reform guidance", "institutions of higher learning financial system".

As the most important part of Chinese public expenditure, education expenditure is to implement performance evaluation management, so as to improve the performance of public expenditure, and to ensure our country's finance is in normal operation. Performance evaluation management refers to the management of input costs and post-evaluation of benefits. The specific process is: to require the relevant financial departments of colleges and universities, combined with the specific expenditure of colleges and universities, the use of appropriate performance evaluation management approach to do an annual estimate of capital investment work to develop expenditure plans to control expenditure, with minimum investment, the highest of the performance. For example: the daily teaching of colleges and universities, professional research projects in colleges and universities, colleges and universities based on investment projects. In this way, university financial personnel should not only understand the project expenditure information of university expenditure, but also grasp the annual expenditure structure of the university, and finally realize its benefit maximization.

\subsection{The role of the implementation of performance management in university expenditure}

As an important part of public welfare undertakings, colleges and universities adopt the management method of performance evaluation, which not only is beneficial to the combination of economy and efficiency of our country's financial expenditure at present, but also manages the process of expenditure effectively. Finally, in the process of expenditure and follow-up management, it 
is convenient for the relevant financial departments of colleges and universities to understand the capital flow and to control the maximum performance of the performance evaluation management system. In this way, the performance evaluation management standards should meet the development needs of colleges and universities; benefit.

The performance evaluation of university financial expenditure is covered in the overall process, including: first, performance management of expenditure; second, performance management of comprehensive benefit evaluation; third, performance management of risk evaluation. Therefore, it is required that colleges and universities play a role of macro-allocation, improve the utilization of funds and promote the development of schools, the role of the implementation of performance evaluation management of university expenditure: (1) to ensure that the local government's fiscal balance is in balance; It can not only show the openness of the local government's financial expenditure, but also further enhance the public's trust in the local government. Performance evaluation of university expenditure, not only reflects the responsibility of the local government to perform the process, but also publicly show the results of the performance. It is noteworthy that, based on the expenditure of colleges and universities, based on the national education policy, taking the local educational benefit as the main content, taking the local economic benefit as the secondary content, promoting the construction of the local key education project, is advantageous to the scientific research project management, Relevant law enforcement departments should strengthen law enforcement, tight control of capital flows, regular disclosure of capital investment information, to avoid the risk of investment decisions due to mistakes, and ultimately promote the rational allocation of educational resources. (2010-2020), it is necessary to construct a supervisory and evaluation system with the characteristics of colleges and universities, and set up a system for the supervision and evaluation of colleges and universities, Strengthen the role of public oversight, avoidance of re-use of funds, and ultimately improve the efficiency of the use of funds [4]. Therefore, the relevant financial departments of universities in China should continuously improve their own asset management level and integrate the existing resources rationally so as to avoid the continuous increase of the debts of colleges and universities. In particular, there are a small number of colleges and universities in our country, duplication of expenditure items and low income level.

\section{The existing problems analysis of performance management of funds expenditure in colleges and universities}

At the present stage, the performance evaluation of the university has made certain achievements, but in the short term, this work is still in the early stage of exploration. The focus of financial budget work of local government is also gradually changing from the traditional division of interests to the current management interests of the local government's financial expenditure, no longer 
stay in the traditional allocation of public resources, although the formation of the characteristics of the university (1) performance management awareness is not strong; means at this stage, most of our financial departments and departments of colleges and universities (financial institutions and departments), the majority of the financial sector, Managers, for the performance evaluation of expenditure management is not enough understanding, management awareness of the reaction is not strong, affected by the traditional factors more serious, especially for the benefit of understanding is not comprehensive, but also remain in the completion of the plan level, not focus, The result of performance management evaluation is not enough attention, no structure to explore. (2) performance management is too procedural; refers to the expenditure management performance in the management process, the relevant management personnel management methods and operating procedures are too procedural. At the same time, there are no corresponding laws and regulations in our country at present, which leads to the imperfect performance management mechanism and the imperfect evaluation standard. The result shows that the performance management mechanism of the university is not perfect. It is noteworthy that some local governments, according to the different expenditure projects of colleges and universities, the development of different management systems, not only can not meet the objectives of performance management, but also in the actual budget process, due to errors in previous results, the impact of late performance evaluation results Value function.

\section{Management measures of performance evaluation of funds expenditure in colleges and universities}

\subsection{Strengthen management awareness and establish the development concept}

It is necessary to strengthen the management consciousness, establish the concept of positive development and improve the management level, so as to deepen the idea of university education goals, cleverly combine the functions of colleges and universities and the performance evaluation management system of the expenditure of colleges and universities in the process of university expenditure, Combine. Under the development of new economic situation, the effective deployment of existing resources, the development of line with the local development needs of institutions of higher learning development route to enhance the efficiency of expenditure, and ultimately to promote the development of local education lay the foundation. Requires college financial sector management, and actively cited the economic management theory, in order to ensure maximum efficiency of capital investment. 


\subsection{The rational integration of existing resources, the development of performance evaluation method}

In the process of university expenditure, the relevant management personnel should be rational integration of existing resources, with the characteristics of colleges and universities to develop performance evaluation methods to the expected return as the goal, according to the actual performance of the local government to adjust again, Brainstorming, rational adoption of the recommendations of relevant technical personnel, the specific method of operation is not only operable, but also by their own technical and economic constraints, the combination of practicality and economy, thereby reducing investment risk.

\subsection{Build a new type of university expenditure performance management model}

In the process of university expenditure, the relevant management personnel should actively construct a new performance management model of university expenditure, take the performance evaluation as the main body, implement the management operation process and strengthen the performance evaluation results.

\section{Conclusion}

Through the research of this paper, it is recognized that there are many factors influencing the management efficiency of university project expenditure. In order to improve its efficiency, it is necessary to take effective measures, such as strengthening the management consciousness, establishing the concept of development, rationally integrating the existing resources, formulating the performance evaluation method and constructing the new mode of performance management. I believe that from the above aspects to be improved, college project expenditure management efficiency will be able to effectively improved, and lay a solid foundation for further promote the development of Chinese colleges and universities.

\section{References}

[1] Ren Ruizhang.Experiment on the Performance Evaluation of University Project Expenditure. Finance and Accounting Research, 55(12), pp.68-70, 2011

[2] Yu Lan. Reflection on the Reform of Performance Evaluation in Institutions Research on the Performance Evaluation Management of Financial Expenditure in Colleges and Universities. Financial Supervision, 8 (5), pp.87- 91, 2013

[3] Qiao Chunhua. Fundamental Concepts of Fund Performance Management in Colleges and Universities. Friends of Accounting, 212(10), pp. 18- 20, 2012

[4] Hubei Provincial Department of Finance Research Group, Wang Wentong, He Dachun, Cao Xingguo, Ma Defu, Cai Hongying. Hubei Province Colleges and Universities budget management innovation research, 9(6), pp.58- 61, 2011 
